\title{
ブラジルと日本の幼児の箱庭制作に見る文化的差異の起源 \\ THE ORIGINS OF CULTURAL DIFFERENCE: \\ SANDPLAY EXPERIMENT STUDY WITH BRAZILIAN AND JAPANESE CHILDREN
}

\author{
坂戸省三*1, 東野 アドリアナ*2, 河内あゆ*3 \\ Shozo SAKATO, Adriana HIGASHINO and Ayu KAWAUCHI
}

\begin{abstract}
Adults' sandplay works gender, and cultural background releases archetypical spatial images. In this study, we will discuss when cultural difference appears and their significance. Sandplay experiments were realized with Japanese and Brazilian children and analyzed according to the direction, the position, and the order the toys were placed in the box, and how long the children played. Japanese children's sandplay works expressed a sense of unity with the surrounding world in contrast to Brazilian children's sandplay works that from an early age separate themselves from the world and had an autonomous tendency.
\end{abstract}

Keymords: Sandplay works, Cultural differences, Archetypical spatial images, Aggressivity 箱庭作品，文化的差異，原型的空間イメージ，攻撃性

\section{1.はじめに}

箱庭作品は、作者個人の心的内容の側面、作者が属する文化に共 通する側面、生物としてのヒトに共通寸る側面が相互に関連しあっ て成立している。これまでの研究で、成人を中心におこなった箱庭 制作実験においては、性別と文化圈別によって共通する空間構成が 箱庭作品に見られた。西洋文化圈、東洋文化圈を問わず大陸の文化 圈の男子が作成した作品には、「男性的一元性の空間イメージ」と 名づけた、一つの中心あるいは軸が全体を統合し、中心を通る垂直 軸、対称性などの特徵をもつ空間構成が多数現れた。それに対して 日本人男子が作成した作品は、「多元性の空間イメージ」と名づけ た多元的、非対称的で水平に広がった空間構成が大多数であった。 また女子においては日本人も留学生も「女性的一元性の空間イメー ジ」と名づけた、住人的、内部的、内包的、一元的な空間構成（後 詳述）が多数を占めた。

本稿では日本人幼児とブラジル人幼児との箱庭作品および制作過 程を比較することで、成人男子における文化的差異および成人女子 における一見したところの共通性といったことがらの、それぞれの 文化における出現の起源について考察する。すなわちブラジル人男 子においては、発達的視点から、男性的一元性の空間イメージが形 態的には、どのような時期に、どのような経緯をたどって現れてく るかを見てゆき、その心理・社会的背景として高い攻撃性が存在し ていることを分析する。またブラジル人女子おいても、日本人女子 と比べて、その表現のなかに高い攻撃性を内在させていることを明
らかにしていく。同時に、ブラジルと比較することで、日本人男女 幼児の特質を改めて考察する。

成人男子箱庭作品おける文化的差異は、ヨーロッパをはじめ大陸 の文化圏の建築や庭園に多く見られる空間的特徵と、日本の建築や 庭園に見られる空間的特徵とに重なるものである。本稿の考察は、 こうした建築におけるいわゆる日本的表現あるいは大陸的表現とい われるものの性格に関して、心理・社会的な側面から分析し、理解 するための新たな視界を開くという意義をもつ。すなわち、本稿は、 そうした表現の背後にある心情の起源を幼児期にさかのぼって理解 する試みである。

参考文献 1 「保育園児の箱庭制作に見る人間の創作行為の起源」 (以下前稿と記す) は、日本の 4 歳児組（4歳から 5 歳）および 5 歳 児組（5 歳から 6 歳）の保育園児を対象におこなった箱庭制作実験 考察である。そこでは箱庭作品を、単純なものからより複雑なもの へと大きく段階分けしたが、本稿ではブラジル人幼児においても同 様の段階分けが存在し、同じ羅列的形式、同じ原型的空間イメージ が現れるという共通性をまず見ていく。次いで差異性として、ブラ ジル人男子においては男性的一元性のイメージおよびその萌芽的状 態が多数現れることや、男女ともに玩具の向き、玩具配置の空間的 広がり方、制作時間などに大きな違いがあることを見、そこに成人 における文化的差異の萌芽が現れていることを考察する。

箱庭制作実験は 2012 年の 9 月にブラジル、ポルト・アレグレ市の プロビンシア・デ・サン・ペドロ校でおこなった。観察者は第 3 筆

\footnotetext{
*1 明石工業高等専門学校 名誉教授・博士 (工学)

$* 2$ 明石工業高等専門学校建築学科准教授・博士 (工学)

*3パシフイックコンサルタンッ(侏) 修士(理学)
}

Emeritus Prof., National Institute of Technology, Akashi College, Japan, Dr.Eng. Assoc. Prof., Dept. of Architecture, National Institute of Technology, Akashi College, Japan, Dr.Eng.

Pacific Consultants Co., Ltd., M.Sc. 
者の河内あゆである。また本稿の論考は第 1 筆者坂戸省三（日本人 男性）と第 2 筆者東野アドリアナ（イタリア系ブラジル人女性）と の議論に基づく（それぞれ日本文化、欧米系文化に属し、男女異な ることから、相互の視点を客観視できる立場にある)。用いた箱庭セ ット（砂を入れた $57 \mathrm{~cm} \times 72 \mathrm{~cm} \times 7 \mathrm{~cm}$ の箱と、人、動物、木、花、乗 り物、家具、建築物、橋、椢、兵器、積み木、その他の多様な玩具 類）は日本もブラジルも同じ内容のものである。箱庭制作実験は作 者に自由に作ってもらうという仕方で進めた。

\section{2. 日本人幼児の箱庭制作における諸類型}

ブラジルと日本の箱庭制作を比較するために、次に前稿で考察し た日本の幼児の箱庭作品に現れる内容や空間的形式、創作行為自体 の発達的展開を示す。前稿では、作品を年齢的、発達的に見ていく ことで、以下のように羅列・混沌の段階、構造化の段階、および両 者の中間的な部分的構造化の段階等に大きく分類した。

なお後述の Table 2、3 は箱庭制作において顕著に目についたこと がらで、特にブラジルと日本の作品を比較することで見てとれた共 通性の高い性質および差異性の大きい性質の出現状況をまとめたも のである注1)。それら諸性質を表記した Table2、3 の項目番号を以 下、項 1、項 2 のように記す。

羅列（全 51 例中 10 例、20\%）：玩具相互の関係をほとんど考慮せ ず、同じようなペースで玩具を次々と並べていくもの。雑然と並べ るものや、写真 N1-JpB58) (写真番号 1、日本人男子、5 歳児組、事 例 8、Number 1, J apanese B oy, 5 years, Case8)の意味、写真下には制 作時間 $9 \mathrm{~min}$ も記入、以下ブラジル人はJpが Br に、女子は B が G となる)のように一方向を向いているもの、N2-JpB 4(5)ように箱の 枠と平行に縦横に置いているものなどがある（項 4 に手前向きよ、

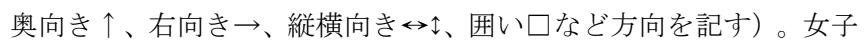
の作品でN3-JpG499ように囲い（項 13）のみが現れる場合がある が、こうした作品も玩具相互には意味的関連が見られないので一種 の羅列である。囲いは女性の原型的イメージである女性的一元性の
空間イメージの囲いの要素のみが先駆的に現れたものと見なせる。

日本人幼児の作品では男女とも、N4，5，6-JPG54)ように、左下 から右上に向けて玩具が置かれてゆき、広がってゆくものが多かっ た（箱庭の中の位置を示寸表記として横軸は左、中、右、縦軸は手 前から奥に向かって下、中、上とする）。Table 2、3 の項 5〜10 に 広がり方を示す注2)。なお Table 2、3 の広がり方の項 5～10 は最初 に全体的に広がるまでの広がり方を示している。

混沌（9 例、18\%）：は N7-JpG4111のように、羅列的に玩具を置く 行為が止まらなくなり、混沌とした様相を呈するもの。混沌の作品 には、最初は N8-JpG4(16)-1 のように、女性的一元性のイメージの一 つの表れである室内空間の様相が現れはするが、玩具が次々と詰め 込まれ、結局はN 9-JpG416-2 の混沌とした状態になるものもある。

構造化（6 例、12\%）：箱庭全体を見て、置かれた諸玩具が何らか の意味連関の中、空閒的に適切に配置されているもの。全体が明確 に場や領域注 3) で構成されていること、またテーマ的まとまりをも っていることなどが構造化の一般的特徵である。N10-JpB 410などが その例である。

部分的構造化（5 例、10\%）：羅列的、混沌的な様相のなかに構造 化の要素が萌芽的に現れてくる場合もある。そうしたもののなかで、 ある程度の骨格が見て取れるものを「部分的構造化」とした。また 羅列・混沌に分類したが、N 1、N2 のように機械的、均質的に並心゙ら れたものではなく、ところどころに「場」あるいは「場的な空間注4)」 がある作例もあった。

テーマを見つけて構造化（2 例、4\%) : 初めは全くの羅列であった が、突然テーマを見いだし、改めて内容のあるものに作り直される 作例である。

変転 $(11$ 例、22\%) : 玩具遊びなどが次々と現れる事例や、作られ た場面が次々と変化していく作例。

その他（8 例、16\%）：全く作らない、あるいはほとんど作らずに 帰る事例。なお、変転、その他に分類したもののなかには、箱庭の 箱の所まで来ずに玩具棚の前に立ちすくむ者や、またN13-JpB5(3)の

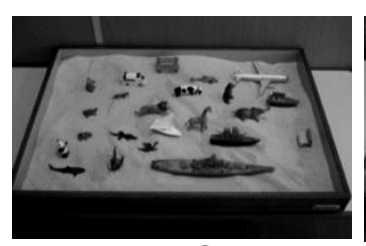

N1-J pB58 9 min

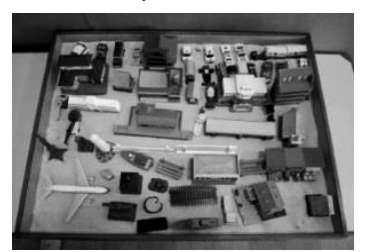

N6-J pG5(4)-3 37min

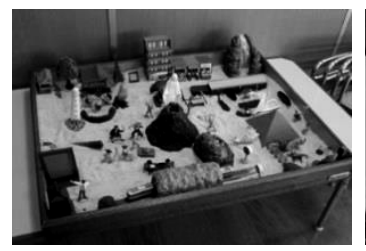

N11-J pB5(15) 56min

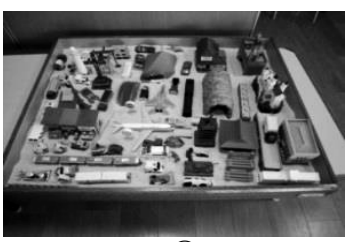

N2-J pB4(5) 37min

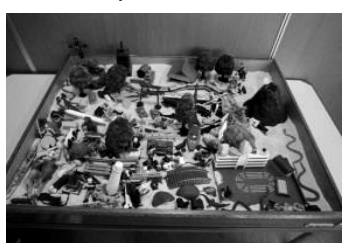

N7-J pG 4(11) 39min

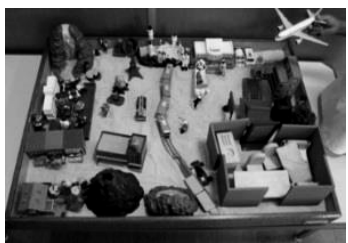

N12-J pG59) 50min

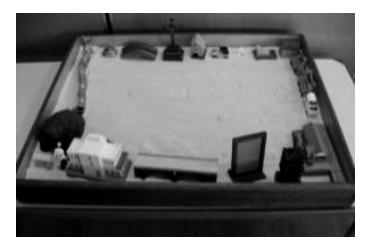

N3-J pG49) 6min

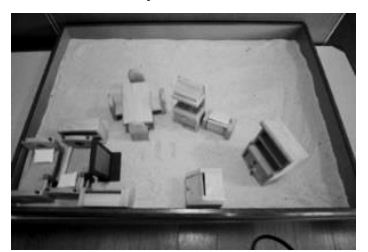

N8-J pG 4(16-1

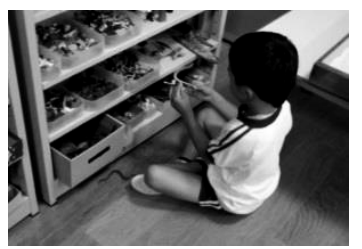

N13-J pB5(3) 39min

Fig.1 J apanese Children's Works 日本人幼児作品

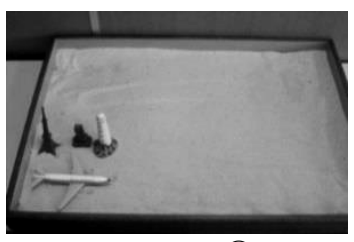

N4-J pG5(4)-1

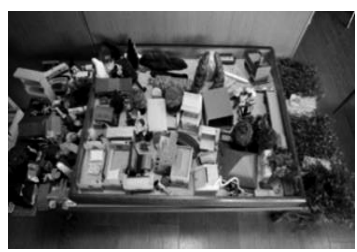

N9-J PG 4(16)-2 45 min

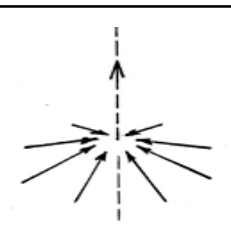

Centrifugal 求心的

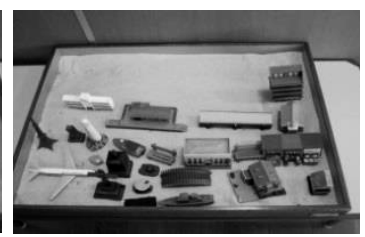

N5-J pG 5(4)-2

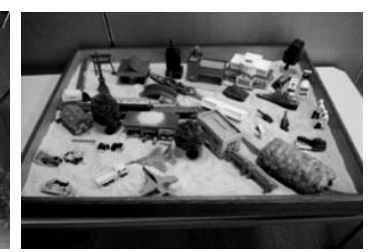

N10-J pB 4(10) 42 min

Fig.2 Male Spatial Singularity 男性的一元性 
ように棚の前で観察者に背中を向けて玩具遊びをする者、棚の中、 棚の前で玩具構成をする者が複数いた。

構造化と原型的空間イメージ : さて前稿で明らかになった重要な ことがらの一つは、幼児の作品において構造化された作品は、男女 それぞれに最初から以下に述べるような普遍的、原型的な形式注5) をとって現れることである。男子の場合は N10-JpB410のように、鉄 道、飛行機、船、工事車両のような乗り物や動物など動くものの多 用（移動・侵入的）、箱の枠を超えて空間的に広がっているイメー ジ（外部的）、いくつかの領域が半ば独立的、半ば連続的に広がっ ているイメージ (多元的) である。こうした移動・侵入的、外部的、 多元的という特徴をもつものを「多元性の空間イメージ」（項 11) と名づけたが、参考文献 2で示したように日本人男子においてこの 形式はどの年齢でも多数現れる。

男子に現れる他の原型的空間イメージの一つとして「男性的一元 性の空間イメージ」（項 12）と名づけた形式がある。このイメージ は、Fig. 2 のようにさらに求心的形式と遠心的形式に分けることが できる。多元的なものが中心あるいは中央の軸に集中するイメージ (求心的形式) と、中心にあるものが多元的なものをまとめ上げ、 支配するイメージ（遠心的形式）である。大陸文化圏の建築および 成人の箱庭作品によく見られるのは遠心的形式である。求心的形式、 遠心的形式のどちらも内に強い攻撃性を秘めたイメージである。日 本では小学 3 年生段階に求心的形式のものが、二つの戦闘集団が中 央付近でぶつかり合う戦いのイメージとして多数現れるが、遠心的 形式の箱庭はどの年齢段階でもほとんど現れない（参考文献 2）。 日本人男子幼児の作品のなかで求心的男性的一元性のイメージの傾 向をもつのはN11-JpB515)で、箱庭のあちこちで戦いが繰り広げられ ていること、中心の火山配置にその要素を見ることができる。

女子の原型的空間イメージとしては「女性的一元性の空間イメー ジ」（項 14）と名づけたものが最も主要なものである。参考文献 4 で見たように、女子の作品ではどの年齢でも人類共通に女性的一元 性の空間イメージが大量に現れる。それは、住人的（人や動物が楽 しげに暮らしている様子など）、内部的（箱庭の枠の中で世界が完
結しているイメージ）、内包的（全体あるいは主要な部分が囲われ ている一ただし内包性・囲いが現れない場合もある）、一元的（「全 体として一つの空間」が中心的な位置をしめる）という特徴をもつ。 N12-JpG59は女子の作品で、右下の囲われた室内空間がそれにあた り、さらに全体として見ても囲われた女性的一元性の空間というふ うに二重の意味でこの空間的形式をなしている注6)

なお「テーマを見つけて構造化」の作品は男女 1例ずつあったが、 構造化として現れるイメージは男子では多元性の空間イメージ、女 子では女性的一元性の空間イメージに他ならなかった。

\section{3. ブラジルと日本の箱庭作品における空間的形式の共通性}

以下ブラジルでの作品を検討する。まずこの節では、日本の作品 と同様、羅列、混沌、部分的構造化、構造化などの段階に分類がで き、年齢が上がると構造化された作品が現れること、また羅列、混 沌段階では同じ空間的形式が現れ、構造化の段階では同じ原型的空 間イメージが現れるという共通性を中心に見ていく。女子 19名（4 歳 4名、5歳 11 名、6歳 4名) 、男子 13 名（4歳 3 名、5歳 5 名、 6歳 5名）である注7)

女子羅列（19 例中 7 例 37\%）：N14-BrG5(2)、N15-BrG5(5)など計 6 例は、日本の作例 N1、N2 と同様に、玩具が箱の枠に平行に置かれ たり、特定の向きに多く置かれたりする機械的配置の例である。 N16-BrG4(2)は囲い（項 13）の配置が萌芽的に見られ、機械的配置と 異なる印象の作品であるが、玩具相互に意味のある関係は見られず、 羅列に分類した。この作品は日本人女子に見られた囲いだけ現れる N3-JpG49)の作例に通じる。

女子混沌（19 例中 5 例 26\%）：羅列と混沌の境界は必ずしも明確 ではないが、量的に一段と多く隙間もなく詰め込まれ、最終的に無 秩序な印象を与える N18-BrG4(3)-2、N20- BrG5(8)-2 など 5 例を混沌 に分類した。N18 は最初 N17 のように下半分の中央にテーブルとイ ス、その両側にベッドというような女性的一元性の空間としての室 内空間が現れたが、結局混沌となった。これは先に示した日本の N8,9-JpG416) と同じ経過である。こうした女子の傾向は混沌に分類し

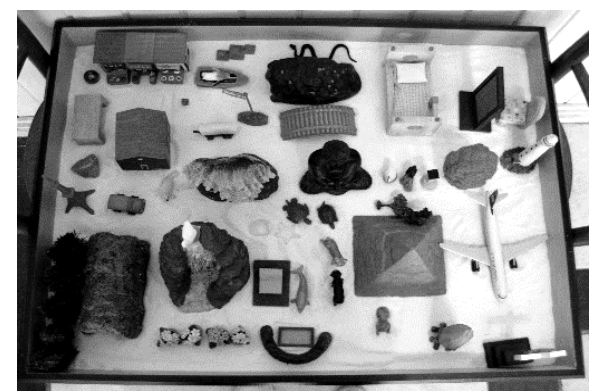

N14- BrG5(2) 19min

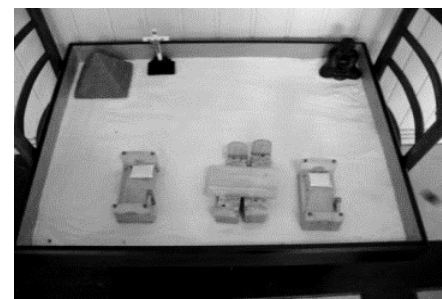

N17-BrG4(3)-1 18min

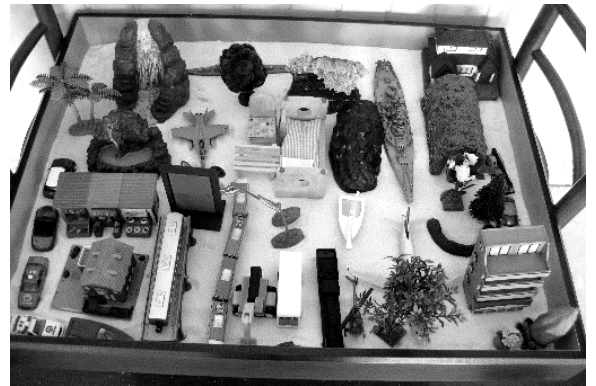

N15-BrG5(5) 8min

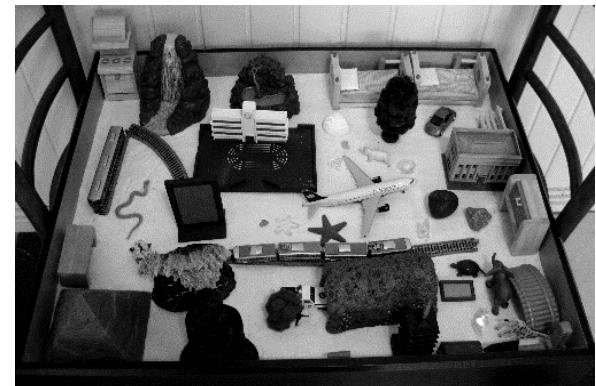

N16-BrG4(2) 12min

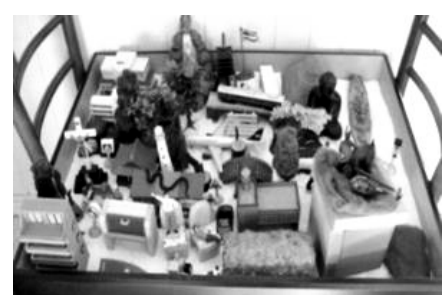

N20-BrG58-2

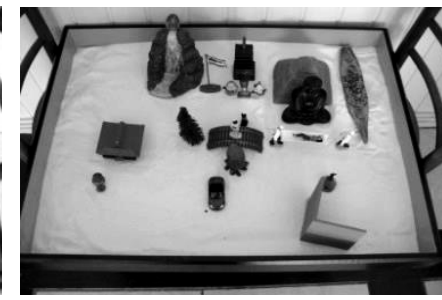

N19-BrG5(8)-1 20min

Fig.3 Enumeration and Chaotic Works 羅列、混沌 


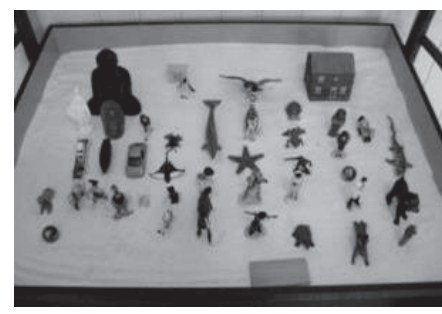

N21-BrB6(1) 16min

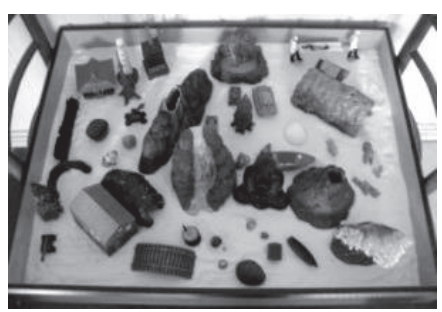

N22-BrB5(1) 11min

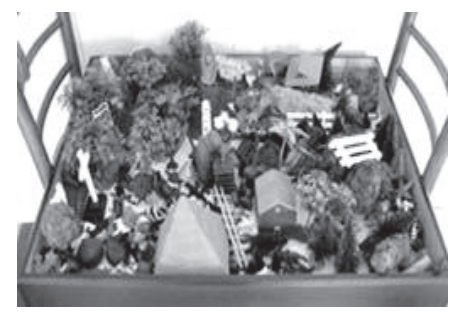

N23-BrB 42) 56min

Fig.4 Enumeration and Chaotic Works 羅列、混沌

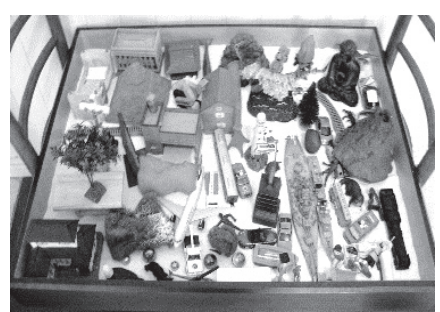

N24-BrB5(3) 17min

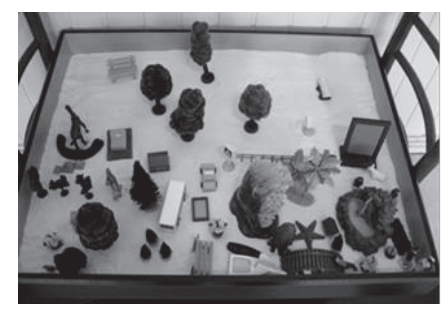

N25-BrG 4(4) 43min

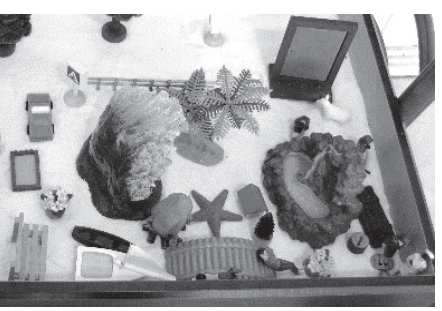

N26-BrG 4(4)-2

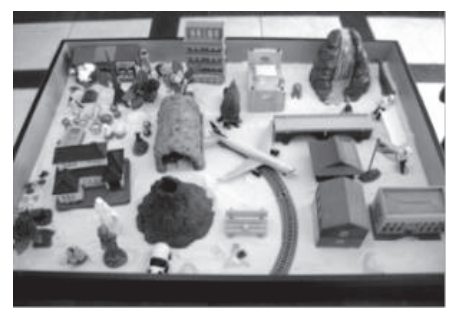

N27-BrG 5111 25min

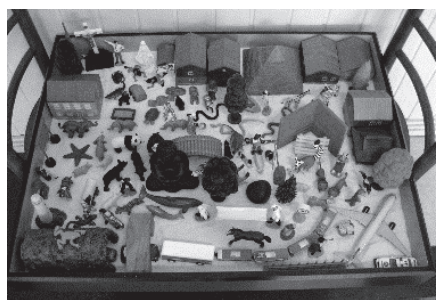

N28-BrG61) 34min

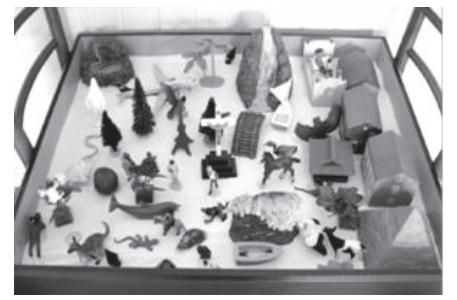

N29-BrG 62) 30min

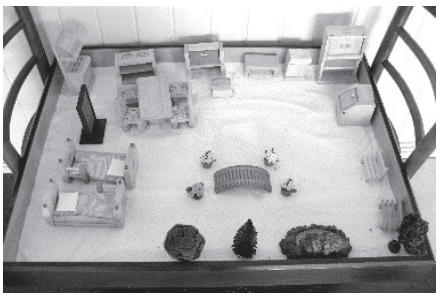

N30-BrG 63) 5min

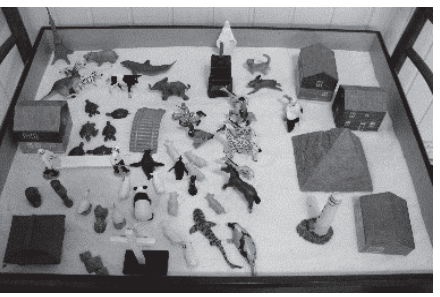

N31-BrG 64) 14min

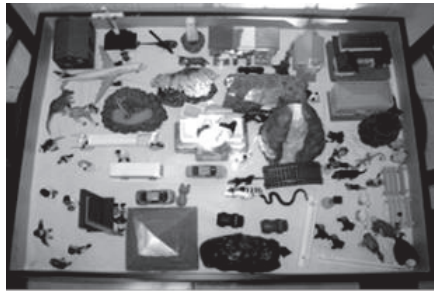

N32-BrB5(5) 22min

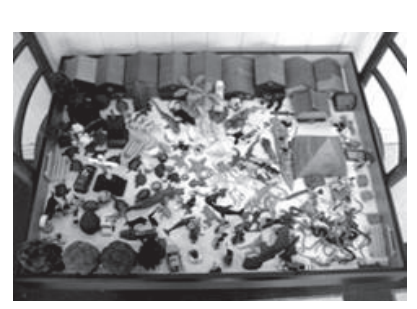

N33-BrB6(2) 41mn

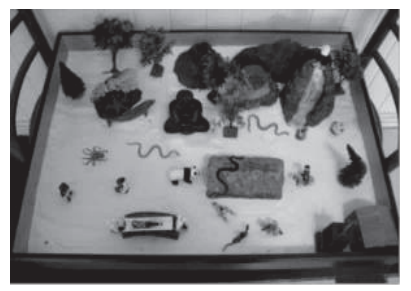

N34-BrB63) 8mn

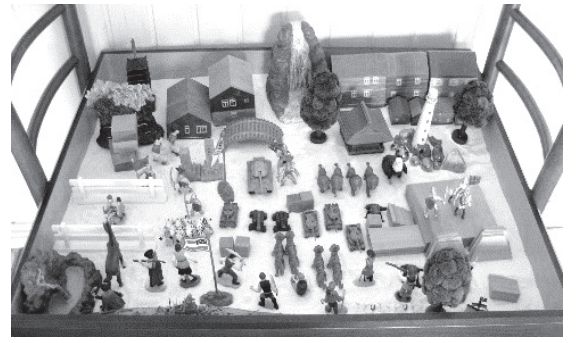

N35-BrB6(4) 28min

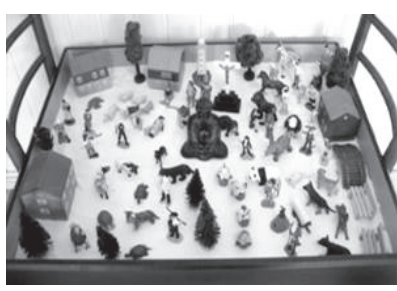

N36-BrB65) 16min

Fig.5 Partially Structured and Structured Works 部分的構造化と構造化

た他の 2 例でも見られた。なお混沌となる前段階では、N19-BrG58) -1 が N20 となったように、縦横向きや手前向きといった玩具向きを とっているものが多い（項 4 にはそれを記す）

男子羅列（13 例中 3 例 23\%）：N21-BrB611は機械的な羅列である が、N22-BrB51)と他 1例は、日本人幼児の箱庭作品にも見られた、 あちこちに「場的な空間」がある作例である。

男子混沌（13 例中 4 例 31\%）：N23-BrB4(2) と他 1 例は詰め込むこ とが止まらなくなった混沌の作品である。N24-BrB5(3)および他 1 例 はN23ほど混沌としていないが、混沌に分類した。

以上のように羅列、混沌の段階では、男女とも玩具が一定の向き に置かれたり、列状に並べられるといった機械的配置が多く現れる ことや、置くことが止まらなくなり混沌とした様相を呈するものが 現れるなど、日本の箱庭作品と共通している。

次に部分的構造化、構造化の作品を検討するが、羅列・混沌段階 の作品が類型的であるのに対して、この段階の作品はより個性的で あるので全作品の写真を示すことにする。

女子部分的構造化（19 例中 4 例 21\%）：N25-BrG4(4)は 4歳の作品
だが、右下の柵やドアで囲われた領域（N26はそこを拡大）は寝そ べる女性や本を読む少年の他数人の人物がいて、女性的一元性の空 間的性格の強い領域となっている。N27-BrG5111動物や乗り物など 多くの玩具が手前向きとなっており羅列的傾向を残寸が、左上の花 が飾られ看護婦がいる領域に女性的一元性の空間の萌芽がある。 N25、N27 はともに一部に女性的一元性の空間様の領域がある作品 である。

N28-BrG611は上側には家々、下側には柵その他で全体的に囲われ ており、そうした面では女性的一元性の要素がある一方で、動物た ちが向き合って対峙する、あるいは一点に集中して向き合う求心的 形式の男性的一元性の要素 (攻撃的要素) があちこちに見られる。 N29-BrG6(2)は動物たちが三々五々平和なようすでつどっており、か つ右上のベッドの上では衫そべる女性と寝転がつて本を読む少年が いる。囲い的要素は右側の建物列だけであり、また羅列的傾向も残 しているが、全体として女性的一元性の空間といえる。

女子構造化（19 例中 2 例 11\%）：N30-BrG6(3)は室内空間としての 女性的一元性の空間である。N31-BrG6(4)は左上のタワーに向かって 
動物たちが集中する求心的形式の男性的一元性の空間である。

以上のように女子の部分的構造化および構造化の作品は、N31を 除いて、原型的空間イメージである女性的一元性の空間としての傾 向が認められる。こうしたことはブラジルも日本も共通する (Table 2、3 の項 14）。なお N28、N31 に男性的一元性の要素があることは 注目に值する。

男子部分的構造化（13 例中 3 例 23\%）：N32-BrB55) は羅列的要素 も残っているが、移動・侵入的、多元的、外部的な性格をもつ多元 性の空間イメージである。N33-BrB6(2)は混沌的様相も呈している が、中心に向かって多くのへビ、カエル、動物、人間が配置された 求心的男性的一元性のイメージである。女性的一元性の空間におけ る囲いは、中の平和な空間を包み守るようにおかれるが、男性的一 元性の空間における囲いは、この例のように、あたかも内部での対 決的、攻撃的な圧力を高める円形競技場のように（あるいは反対に 周囲に対する城塞のように) 置おかれることがある。N34-BrB6(3)は 求心的および遠心的両方の要素をもつ（多元性の空間イメージの傾 向も存在寸る)。求心的要素としては最初に中上に置おかれたピラ ミッド（途中で火山に入れ替わる）、トンネルの両端で対峙的に向 き合うパンダと騎馬人物、トンネル上で向き合うへビとトカゲ、中 下の求心的に向き合う騎士とドラゴン、遠心的要素は中上の大仏の 他、右上滝の上に全体を睥睨するように置かれた白頭のワシである （こうした高さの表現も男性的一元性の特徴である）。

男子構造化（13 例中 2 例 15\%）：N35-BrB644)は中央より下半分の 猟師、刀を振りかざす海賊、トラなどによる集団（左下に戦艦も隠 れている）と、上半分の戦車、騎士、ライオンなどによる軍団との 対決シーンである。他にも右中の舞台では騎士が戦っている。求心 的男性的一元性のイメージはしばしば二つの勢力の戦闘シーンのか たちをとるが、この作品はそれに当たる。N36-BrB6(5)は中央の大仏 が全体構成を支配する遠心的男性的一元性のイメージである。

以上のように男子の部分的構造化、構造化の作品が「多元的な空 間イメージ」および「男性的一元性の空間イメージ」という原型的 形式をとって現れることは日本と共通する。日本では前者が大半で あるのに対して、ブラジルでは後者が大半を占める（項 11、12）。

その他および変転：日本では「その他」として分類した「全くあ るいはほとんど作らない例」や次々と場面が変わる「変転」の例が、 全 51 例中、それぞれ 8例 16\%、11例 22\%もあったのに対して、ブ ラジルでその他に分類したのは、全 32 例中、「ほとんど作らず」に あたる N37-BrG511、N38-BrB4(1)の 2 例のみであり、変転の例はな い。N37 はペンギンを右下に埋め、標識を左中に埋めておおりにな った。N38はこれだけの玩具をおいておわりになった。

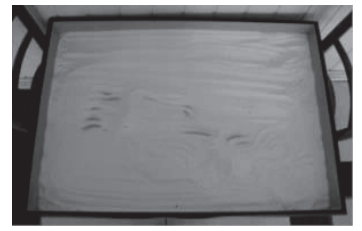

N37-BrG51) 1min

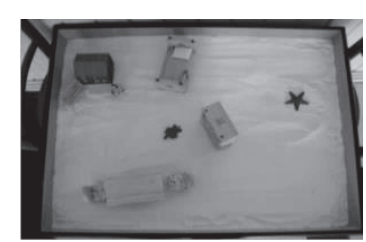

N38-BrB4(1) $2 \mathrm{~min}$

Fig.6 Others Works その他

\section{4. ブラジルと日本の箱庭制作における差異とその意味の考察} ブラジルと日本では攻撃的表現および男性的一元性の空間イメー
Table 1 Comparison of Patterns Appearance Rate 出現率の比較

\begin{tabular}{|c|c|c|c|c|c|c|c|c|c|}
\hline & \multicolumn{3}{|c|}{$\begin{array}{c}\text { 攻撃性 } \\
\text { agressivity }\end{array}$} & \multirow{2}{*}{$\begin{array}{l}\begin{array}{l}\text { 向き toys } \\
\text { direction }\end{array} \\
4 \quad \downarrow \\
\end{array}$} & \multicolumn{4}{|c|}{$\begin{array}{c}\text { 空間的拡大 } \\
\text { spread }\end{array}$} \\
\hline & & $\begin{array}{c}1 \text { 戦い } \\
\text { battle }\end{array}$ & $\begin{array}{l}2 \text { ヘビ } \\
\text { snake }\end{array}$ & $\begin{array}{c}12 \text { 男性一元 } \\
\text { singurality }\end{array}$ & & $\begin{array}{c}5 \text { 左小右 } \\
L \rightarrow R\end{array}$ & $\mid \begin{array}{c}6 \text { 下 } \rightarrow \text { 上 } \\
D \rightarrow U\end{array}$ & $\begin{array}{c}8 \underset{U \rightarrow D}{\text { 上 } \rightarrow \text { T }} \\
\mathrm{U}\end{array}$ & $\begin{array}{c}9 \text { 中央 } \rightarrow \text { 周辺 } \\
\mathrm{C} \rightarrow 0\end{array}$ \\
\hline \multirow{2}{*}{ Male } & $\mathrm{Br}$ & $46(6 / 13)$ & $46(6 / 13)$ & $80(4 / 5)$ & $43(3 / 7)$ & $34(4 / 13)$ & $34(4 / 13)$ & $23(3 / 13)$ & $38(5 / 13)$ \\
\hline & $J p$ & $50(11 / 22)$ & $23(5 / 22)$ & $22(2 / 9)$ & $17(1 / 6)$ & $65(11 / 17)$ & $59(10 / 17)$ & $0(0 / 17)$ & $6(1 / 17)$ \\
\hline \multirow[b]{2}{*}{ male } & $\mathrm{Br}$ & $22(4 / 18)$ & $56(10 / 18)$ & $33(2 / 6)$ & $58(7 / 12)$ & $44(8 / 18)$ & $22(4 / 18)$ & $44(8 / 18)$ & $28(5 / 18)$ \\
\hline & $J p$ & $0(0 / 24)$ & $25(6 / 24)$ & $0(0 / 4)$ & $8(1 / 13)$ & $61(11 / 18)$ & $56(10 / 18)$ & $17(3 / 18)$ & $6(1 / 18)$ \\
\hline
\end{tabular}

ジの出現率、羅列・混沌における玩具の向き、玩具を配置していく 時の広がり方、制作時間において著しい差異が見られた。

Table2、3では文化的差異が分かりやすいように、日本人には少 なくブラジル人に多い内容はのように黒塗りで表示するか、欄に 網掛けをした。○はその特徴が明確に現れた場合、 ロは完全ではな いがほとんどその状態である場合、 $\triangle$ は低程度に現れた場合を示す。 なお特に日本人幼児の場合、まったく作らずあるいはほとんど作ら ずに帰った者、N13-JpB5(3)のように棚の前に留まった者や砂箱での 玩具遊びだけだった者など、表中の諸項目に該当しない場合一を記

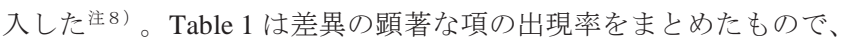
左の数字は\%を表し、（）内は出現数／母数を表す。母数は該当 しない事例を除いた数である。

攻撃性 : 臨床心理学でいう攻撃性は、何かに向かっていくこと、 自分の存在の主張、積極的に他者に接近し、関係を求めること等々 の根底にある力動として広い意味で使われる。幼児の箱庭では、前 稿で見たように、戦いの場面、兵器の使用、へビ（極彩色のへビ） の使用、男性的一元性の空間イメージなどのかたちで現れる。戦い (項 1) で○は戦闘や対峙・対決場面、 $\square$ は軍艦や戦闘機等兵器（複 数）使用のみを表す。へビ（項 2）は複数あるものに○、1匹だが目 立つものを 1 と表記している。

以下、Table1の出現率を見ていくと、男子では、戦いに関して日 本とブラジルの出現率はどちらも5 割程度であるが、へビはブラジ ルが 5 割弱で日本の 2 倍ある。女子で戦いは日本では 0 例であるの に対してブラジル 2 割強、へビはブラジルが 5 割強で日本の 2 倍強 ある。

「男性的一元性のイメージ」（項 12）は攻撃性を内在させたイメ ージであるが、それが形をとって現れるのは構造化の進んだ段階で ある。部分的構造化および構造化の作品（日本では「テーマを見つ けて構造化」も含む) で見ると、男性的一元性のイメージの出現率 はブラジル人男子が 8 割で日本人男子の 4 倍弱ある。日本人男子の 多くは多元性のイメージである。同様に女子で男性的一元性のイメ ージは日本では 0 例であるのに対して、ブラジルでは $1 / 3$ の作品に その要素が見られる。以上のように攻撃性は男女ともブラジルが高 い。特にブラジル人男子で男性的一元性のイメージの出現率が高い。

配置、羅列の玩具向き: 羅列・混沌の作品では玩具が特定の向き に置かれたものが多い。羅列・混沌における玩具の向き（項 4) を見 ていくと、日本とブラジルの大きな違いはブラジルの作品では手前 向きが多いことである。N21-BrB611がその典型である。ブラジルで は男女ともに動物や乗り物といった動くものが箱の上側から下側ま で手前を向いており、玩具が全体的に作者の方へ押し寄せてくると いう印象のものが多数ある。また玩具を縦長の形式で並べる傾向も 認められる。女子から見ていくと、N15-BrG5(5)にその傾向が強く現 
Table 2 Brazilian Children's Works Analysis ブラジル人幼児の箱庭作品の分析
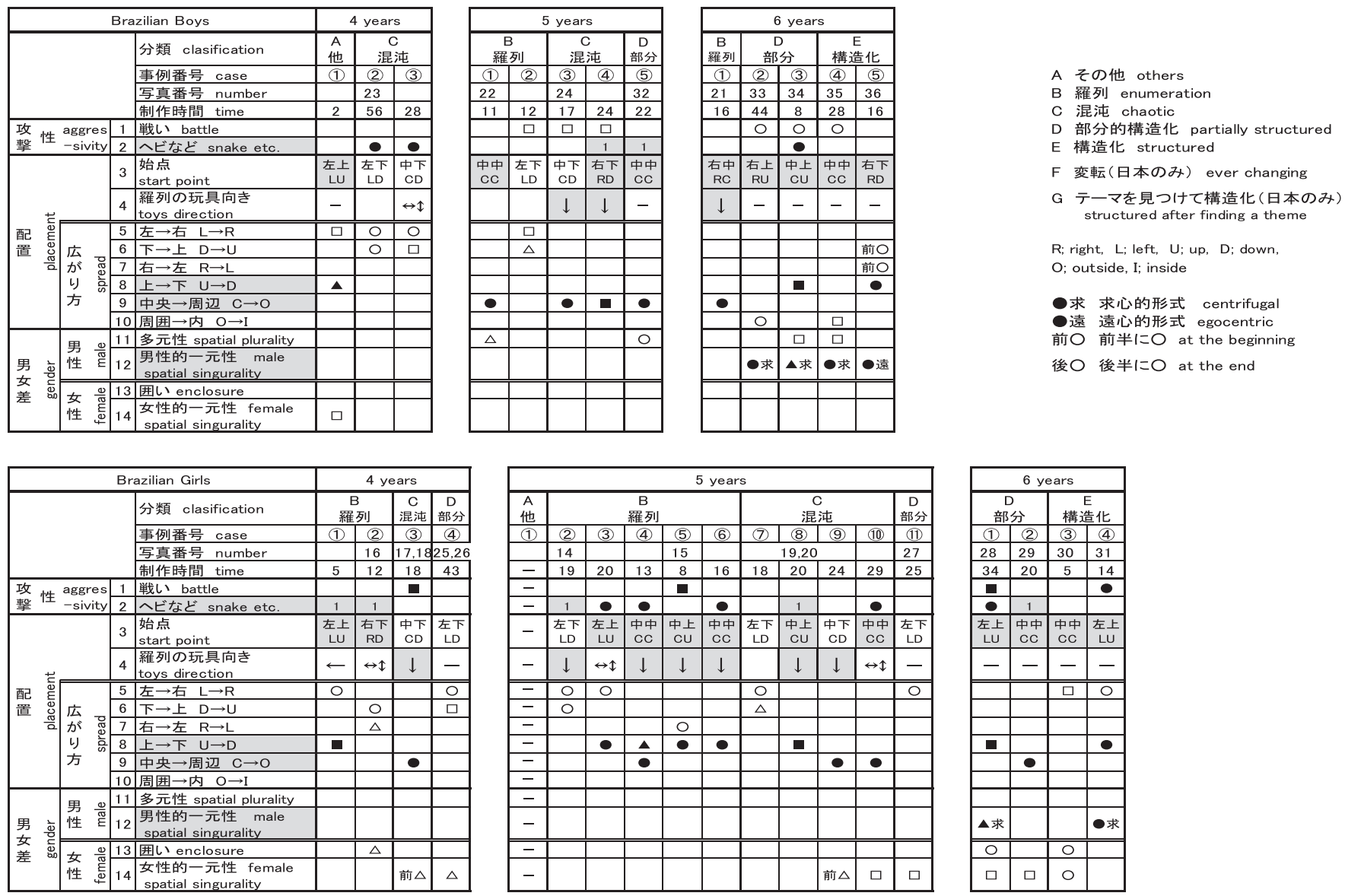

れている。他に N14-BrG5(2)、N18-BrG4(3)、N20-BrG5(8)など計 7 例 にその傾向が見られた。

女子で手前向きは羅列・混沌の 6 割弱、男子ではN21の他に N24BrB5(3) と他 1 例があり、手前向きは 4 割強ある。日本の羅列・混沌 の作品中で建物や人物が手前向きに置かれる例は男女各 1 例ずつあ るが、ブラジルのような押し寄せてくる印象のものはない。

これに関連して興味深いのは戦艦（あるいは駆逐艦）の置かれた 向きである。女子では戦艦が置かれた N15-BrG5(5)、N18-BrG4(3)、 N20-BrG5(8)の3 作品とも手前向きで、男子では N24-BrB5(3)、 N33-BrB6(2)が手前向き、他 1 例が斜め手前、N35-BrB644（左下にあ り枠でほとんど隠れている）と他 1 例が右向きである。一方で日本 人幼児に関しては、男子ではN1-JpB58のように、戦艦が使われた 4 作品のうち 3 作品が右向き、残りが右上向きで、女子では戦艦は 途中て使われてもその後に撤去された例があるだけである。つまり 手前向き戦艦は男女を通じて0例である。

このように作者に対して向かってくる配置の意味はどのように解 釈できるだろうか。例えば男子の N21-BrB611)から、少し空想を飛 躍させれば、戦い前の訓示をする将軍に向かって整列している軍団 とでもいった情景を連想することができる。この作品は、閲兵とま ではいかなくとも、整列する玩具達を作者自身が支配しているとい う感覚を表しているものであろう。あるいは逆に女子の N15-BrG5 (5)などは N39 $\rightarrow \mathrm{N} 40 \rightarrow \mathrm{N} 41$ のように置かれたが、これは作者に向か ってくる外界の圧力、あるいは圧迫感を表していると解釈できる。 男子の N24-BrB6(4)も同様に外界の圧力を表している可能性がある
（ただし広がり方は中央から周辺）。支配であれ、外界の圧力であ れ、どちらにせよ、そこには世界と対峙的に向き合う自分という在 り方が現れている。そして両者の関係は、N15、N24のような外界か ら圧力を受ける側が外界を支配する側に反転するとき、それは N21 のような外界支配のかたちになるといえる。そして両者間の移行時 点を表すものとして、男子の N35-BrB64)の上下の軍団が対峙する空 間構成および女子の N31-BrG6(4)の左上の一点へ攻め上がるような 構成の求心的男性的一元性のイメージがあると解釈することができ る。そしてその移行が達成されたとき、特にブラジル人男子の場合 は、N36-BrB6(5)のような攻撃性を内に秘めた遠心的男性的一元性の イメージが現れると考えられよう。こうした過程の背景には、先述 のブラジル箱庭に見られる攻撃性の高さ、つまり積極的に自己主張 し、世界と対峙的に関わる自分といった在り方があるといえる注 9)。

配置、広がり方: 特に羅列・混沌の段階では玩具を機械的に置い ていくことが多いので、左から右、上から下のように広がるものが 多いそうした広がり方にも日本とブラジルでは大きな差異がある。 Table1、2、3からわかるように、日本人幼児の場合、男女とも左 $\rightarrow$ 右（項 5）、下 $\rightarrow$ 上 (項 6) が圧倒的に多い。一方ブラジルでは、男 子は中央 $\rightarrow$ 周囲（項 9）が多く、女子は N39 $\rightarrow N 41$ のように上 $\rightarrow$ 下 (項 8) が多い。

日本の幼児においては左下から右上に向けて広がっていくことの 意味を考える上で、緘黙女览に対して行われた箱庭療法の事例注 10$)$ が示唆的である。箱庭療法では左側が作者の内的世界、無意識界を、 右側が外的世界、意識界を示すとされる注 11)。その症例では初回は 
Table 3 Japanese Children's Works Analysis 日本人幼児の箱庭作品の分析

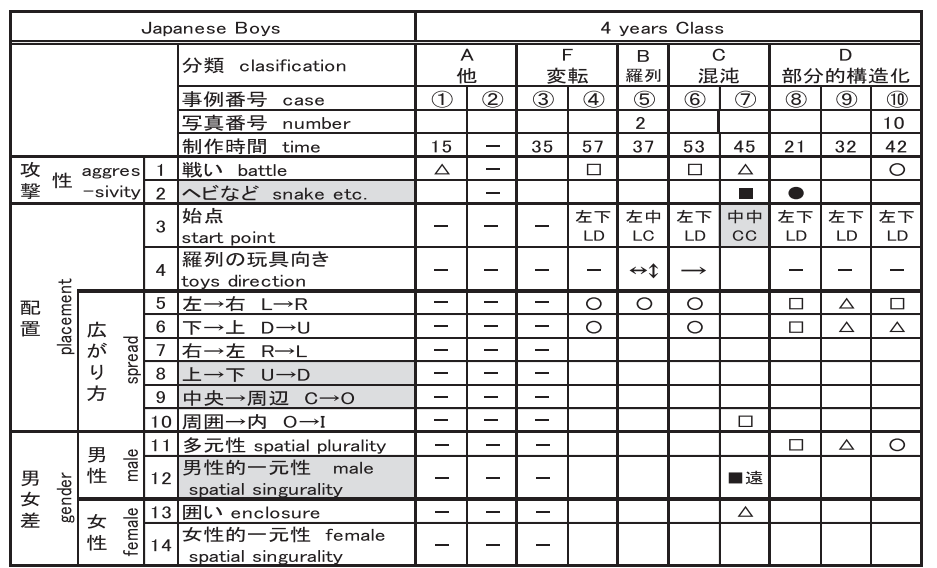

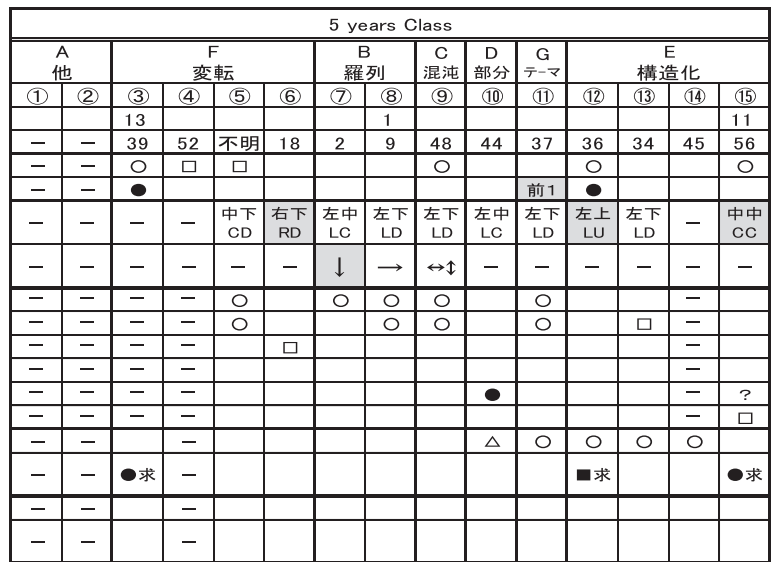

\begin{tabular}{|c|c|c|c|c|c|c|c|c|c|c|c|c|c|c|c|c|c|c|c|c|}
\hline & & Jap & anese Girls & & & & & & & & 4 ye & ars C & & & & & & & & \\
\hline & & & 分類 clasification & & A & & & F & & & 8 & & & & & & 涑 & & & $\begin{array}{l}D \\
\text { 部公 }\end{array}$ \\
\hline & & & 事例番号 case & (1) & (2) & (3) & (4) & (5) & (6) & (7) & $(8)$ & & (10) & (11) & (12) & (13) & (14) & (15) & (16) & (17) \\
\hline & & & 写真番号 number & & & & & & & & & 6 & & 7 & & & & & 8,9 & \\
\hline & & & 制作時間 time & - & - & 8 & 26 & 46 & 60 & 44 & 25 & 6 & 11 & 39 & 51 & 51 & 63 & 26 & 45 & 6 \\
\hline 攻性 & aggres & 1 & 戦い battle & - & - & & & & & & & & & & & & & & & \\
\hline 揧恃 & -sivity & & へビなど snake etc. & - & - & & & & & & & & & - & & & 1 & & -1 & \\
\hline & & 3 & \begin{tabular}{|l|} 
始点 \\
start
\end{tabular} & - & - & $\begin{array}{l}\text { 中中 } \\
\text { cc }\end{array}$ & - & $\begin{array}{ll}\text { 左下 } \\
\text { LD }\end{array}$ & & $\begin{array}{ll}\text { LTF } \\
\mathrm{LD}\end{array}$ & $\begin{array}{ll}\text { 左下 } \\
\mathrm{LD}\end{array}$ & 左上 & 左上 & \begin{tabular}{|l} 
右下 \\
$\mathrm{RD}$
\end{tabular} & $\begin{array}{ll}\text { 左下 } \\
\text { LD }\end{array}$ & \begin{tabular}{|l} 
左中 \\
LC
\end{tabular} & \begin{tabular}{|l|l} 
左上 \\
LU
\end{tabular} & $\mid \begin{array}{c}\text { 左下 } \\
\text { LD }\end{array}$ & $\mid \begin{array}{c}\text { 左F } \\
\text { LD } \\
\end{array}$ & $\begin{array}{l}\text { 左上 } \\
\text { Lu } \\
\end{array}$ \\
\hline & & & $\begin{array}{l}\text { 羅列の玩具向き } \\
\text { toys direction }\end{array}$ & - & - & - & - & - & & $\pi$ & $\uparrow$ & $\square$ & $\leftrightarrow \uparrow$ & $\leftrightarrow 1$ & $\leftrightarrow 1$ & $\leftrightarrow \uparrow$ & & $\leftrightarrow 1$ & $\leftrightarrow \downarrow$ & - \\
\hline 配 & & 5 & 左 $\rightarrow$ 右 $\mathrm{L} \rightarrow \mathrm{R}$ & - & - & - & - & & & 0 & 0 & & & & 0 & 口 & 口 & 口 & 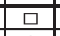 & 0 \\
\hline 置 & & 6 & 下 $\rightarrow$ 上 $\mathrm{D} \rightarrow U$ & - & - & - & - & & & 0 & 0 & & & 0 & ㅁ & 口 & & $\square$ & 0 & \\
\hline & 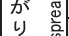 & & \begin{tabular}{|l|l|} 
右 $\rightarrow$ 左 & $R \rightarrow L$ \\
& $\mathrm{~N} \rightarrow \mathrm{U}$ \\
\end{tabular} & $\begin{array}{lll}- & \\
- & & \end{array}$ & $\frac{-}{-}$ & $\begin{array}{ll}- \\
-\end{array}$ & $\frac{-}{-}$ & & & & & & & & & & $\mathbf{n}^{-}$ & & & - \\
\hline & 方 & & 中央 $\rightarrow$ 周辺 $\mathrm{c} \rightarrow \mathrm{O}$ & - & - & - & - & & & & & & & & & & & & & \\
\hline & & 10 & 周囲 $\rightarrow$ 内 $\mathrm{O} \rightarrow \mathrm{I}$ & - & - & - & - & & & & & 0 & 0 & & & & 0 & 0 & & \\
\hline & & 11 & 多元性 spatial plurality & - & - & - & - & & & & & & & & & & & & & \\
\hline & 性 舀 & & $\begin{array}{l}\text { 男性的一元性 male } \\
\text { spatial singurality }\end{array}$ & - & - & - & - & & - 求 & & & & & & & & & & & \\
\hline & $=$ & 13 & 国い enclosure & - & - & -1 & $\begin{array}{llllll}- & & & & \end{array}$ & $\square$ & & & & 0 & 0 & & & & 0 & 0 & & $\Delta$ \\
\hline & & & $\begin{array}{l}\text { 女性的一元性 female } \\
\text { spatial singuality }\end{array}$ & - & - & - & - & & & & & & & & & & & & 前口 & o \\
\hline
\end{tabular}

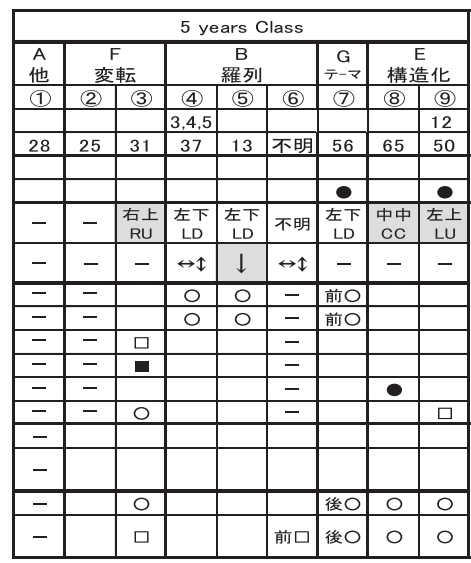

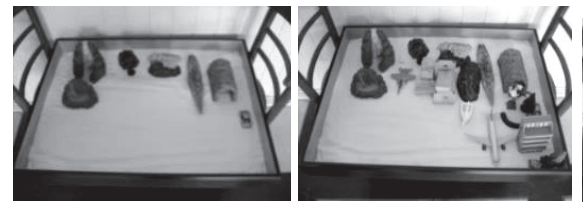

N39-BrG5(5)-1

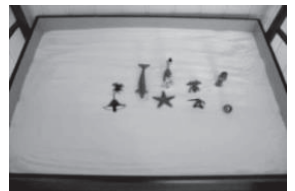

N42-BrB6(1)-1
N40-BrG5(5)-2

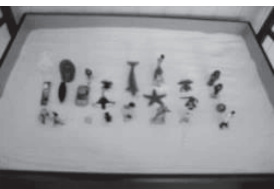

N43-BrB6(1)-2

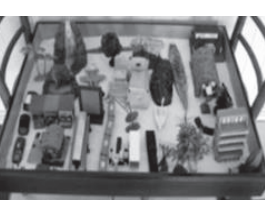

N41-BrG5(5)-3

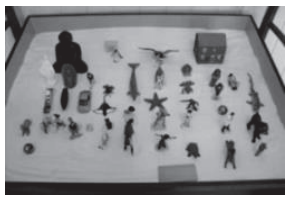

N44-BrB6(1)-3

Fig.7 Spread 配置、広がり方

左下隅に縮こまるように玩具が置かれただけであったが、その後右 上に向けて一歩ずつ配置空間を広げてゆき、 1 年かけてようやく全 体に広がった箱庭作品になったのである。左側は内界、右側は外界 を表すと考えると、この場合、少しずつ空間を広げていった作品に は作者自身が投影されている。またこの過程は、セラピストに見守 られ受け入れられることで次の一歩の歩みが可能となったもので、 いわば作者とセラピストが一緒になって、一体感の上に進められた ものである。同様に左から右へと箱庭での領域を広げていった日本 の幼児達の箱庭作品は、彼らを取り巻く世界（箱庭観察者および保 育園、家庭など）に受け入れられ、支えられて一歩一歩を踏み出し ていることを自ずと表していると考えられよう。つまりこうした日 本人の箱庭作品は幼児と取り巻く世界との一体的傾向を示している

と解釈することが可能である。

一方でブラジルの並べ方の意味はどのように解釈できるだろう か。Table2 のブラジル人男子を見ていくと、最も低年齢の 4 歳では 3 人のうち 2 人が左下 $\rightarrow$ 右上（項 $5 、 6$ ）である。これは上記日本人 の傾向と同じである。しかし 5 歳児 5 名と 6 歳の羅列の 1 名の計 6 人を見ると 5 名が中央 $\rightarrow$ 周辺 $($ 項 9 ) 一と広がっている。例えばN21$\mathrm{BrB6}$ (1) $\mathrm{N} 42 \rightarrow \mathrm{N} 43 \rightarrow \mathrm{N} 44$ のように広がった。これらの羅列的な表 現において中央から置き始めるというかたちで、中心をもつ男性的 一元性の空間イメージの性質が先駆的に現れていると解釈できる。 それは、日本人幼児に見られるように箱のなかで少しずつ外界に向 かって空間を広げていくのではなく、まず中央部分を押さえること で、最初から箱の中の空間全体を支配しているということを意味す ると考えられる。6 歳のこの作者以外の 4 人の作品は構造化の段階 一と進んだものだが、全てが求心的あるいは遠心的な男性的一元性 の空間イメージの要素をもつ（動物や人物の対峙 N33-BrB62(2、N34BrB6(3)、軍団の対峙 N35-BrB6(4)といった求心的形態、大仏による遠 心的形式 N36-BrB6(5)。なお求心的形式は外界一の進撃のイメージ、 遠心的形式は外界での自律のイメージ）。つまり5歳段階での羅列 における中央から置くという男性的一元性の先駆から、6 歳での男 性的一元性の空間イメージ成立へと進んでいくのである。参考文献 5 で示したようにヨーロッパを始め大陸の諸文明に属する男子の箱 庭には男性的一元性の空間イメージが多いが、その起源は、今見た ように、すでに幼児段階にあるといえるだろう。

ブラジル人女子においては 5 歳の羅列・混沌段階の 9 人の内 5 人 
が、先述の $\mathrm{N} 39 \rightarrow \mathrm{N} 40 \rightarrow \mathrm{N} 41$ のように上 $\rightarrow$ 下 (項 8) へと置いていっ た注 12$)$ 。また残り 4 人のうち 3 人が中央から周辺である。これは何 を意味しているのであろうか。女子において最初に現れ、また最も 一般的な原型的空間イメージは女性的一元性の空間イメージであ る。それは N12-JpG59、N30-BrG6(3)の囲いが端的に示すように囲 われた領域、空間という性質をもつ。そして上辺から下に向かって 並べていくことは、箱の中の空間全体を最初から領有するというこ とを意味寸ると解釈可能である。それはブラジル人男子が中心を押 さえることで、最初から箱の中の空間全体を支配するということと 対をな寸ものと考えられよう。日本人幼児が左（内界）から右（外 界） 一一歩一歩空間を広げていくのとは対照的に、これらの事実は ブラジル人幼児においては男女とも早い段階から箱の空間全体をわ がものにしていることを示唆している。日本の左から右への広がり が世界との一体感を表しているのと反対である。すなわちブラジル の並べ方は自律的、分離的傾向を表すといってよいであろう。これ はブラジルの手前向きの多さから分析した「世界と対峙的な在り方」 と同じ結論である。

周囲から（項 10）は日本、ブラジルを問わず、女子では女性的一 元性の空間にともなう囲いを最初につくることと対応している。男 子では男性的一元性のイメージで、周辺から中央に向かって構成さ れていく場合が多い。

配置、始点: 始点 (項 3) は最初に置かれた玩具の位置を示す。ブ ラジルでは男女ともに早い段階から箱の空間全体をわがものにして いるが、そのことをより端的に示しているのが始点注 13 ) を示した Fig.8である。この図でブラジルと日本の違いは一目瞭然である (Table 2、3 の項 3 始点では日本人に多い左下、左中、中下以外を 網掛けにした）。日本人で左下箱外は、作らずに帰ったか、棚の前 に留まった人数を表す。なお砂箱での玩具遊びだけなどは、どこか ら始まったとも言えないのでカウントしていない。

日本人男子を見てみると 4 歳児組は左下が圧倒的で、5 歳児組に なると右や上がいくらか増える。しかし右中、中上、右上は皆無で ある。日本人女子もおおよそそうした傾向がうかがえるが、女子で 左上が多いのは、女子は先述のように領域を囲うという傾向がある ためと考えられる（左上 5 人、右上 1 人は全て囲いを作っている）。 そしてその傾向はブラジル人女子でより顕著である。ブラジル人男 子を見ると、 4 歳児は左下、中下、左上各 1 人だが、 5 歳児では中中
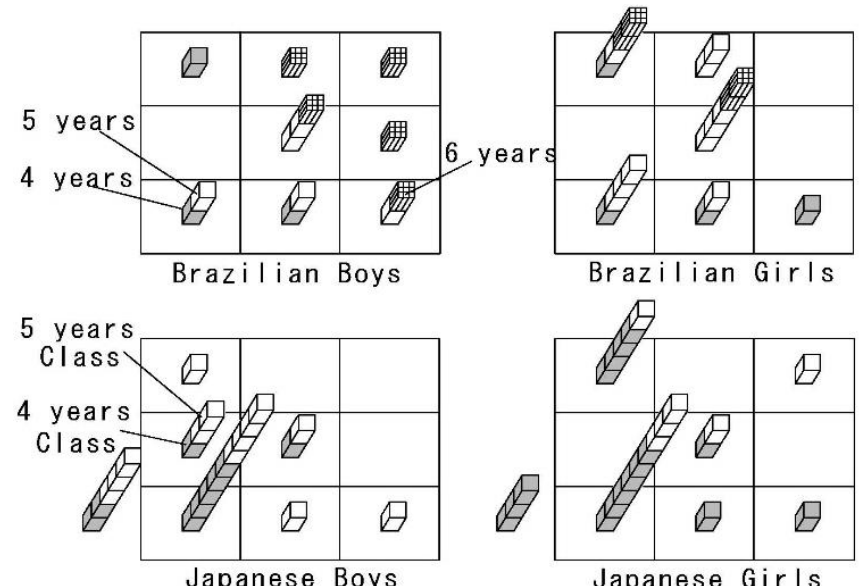

Japanese Girls

Fig.8 Toys Placement Start Point 始点
が 2 人で、一番多くなり、6 歳児になると中中および右側、上側に 偏る。ブラジル人女子の年齢的変遷も男子と似た傾向を示すが、男 子ほど右上の方向への移行は強くない注 14$)$ 。日本では、作らず帰る 幼児あるいは棚の所に留まり砂箱に作らない幼児（N13-JpB5(3)な ど）、いわば箱の左下まで行けない幼児が男子で 25 人中 5 人、女子 で 26 人中 3 人いる。一方ブラジルでは 0 人である。箱庭の右側は 外界を表すが、以上のことから積極的、攻撃的に外界へと向かって いく力はブラジル人の方が強いことがわかる。そしてその力は年齢 が上がるにつれてさらに強くなる。

制作時間：日本人は男女とも積極性、外向性などの傾向はブラジ ル人より弱いが、日本人幼児の場合、ひとたび作り始めると圧倒的 な熱心さを発揮する。Fig.9 は作らずに帰った者、ほとんど作らずに 帰った者を除いた幼児の制作時間の分布を表したものである。ブラ ジルでは男女とも 10 分以上〜20 分未満が最も多いのに対して、日 本の場合、男子は 30 分以上 40 分未満が最も多く、女子は 50 分以 上が最も多い。30 分以上は日本では男子 21 人中 16 人 $(76 \%)$ 、女 子 23 人中 13 人 $(57 \%)$ を占めるのに対して、ブラジルでは男子 13 人中 2 人 $(15 \%)$ 、女子 18 人中 2 人 $(11 \%)$ である。平均時間を比 べると日本の男子 36 分、女子 35 分（男女計 36 分）、ブラジルの男 子 22 分、女子 19 分（男女計 20 分）となる。

前稿で紹介したように、日本の場合「箱庭、楽しい」と言いなが ら作ったり、45分かけて玩具を詰め込んだ後、さらに「もう一回す る」と言ったりと、箱庭制作を遊びとして楽しんで夢中になってい る様子がうかがえる。一方ブラジルの場合、日本人のように遊ばず に、「課題としてとらえている」という印象を受けた注15)。「自分 の遊び」としてではなく「課題」として捉えること自体、外界と自 分との分離を示すと解釈可能である。

なお日本では箱庭の場面が次々と変わっていく「変転」および「テ 一マを見つけて構造化」が全事例 51 例中計 13 例（25\%）あるが、 ブラジルではない。これは早い段階で制作が終わり、次々と変転し ていくという事態が起きないためと考えられる。このような日本人 幼児の特徵は、日本人一般の制作等の行為に見られる丁寧さ、勤勉 さなどの起源である可能性がある。

\section{5. 結語}

原型的空間イメージ出現という共通性 : 前稿では、日本人幼览に おいて構造化された箱庭作品が現れるときに、男子では多元性の空 間イメージおよび男性的一元性の空間イメージ、女子では女性的一 元性の空間イメージをとって現れることや、参考文献 3 で考察した ように生物学的由来をもつものであることから注 1 6)、それらを原型 的空間イメージであるとした。そして、それらが原型的空間イメー

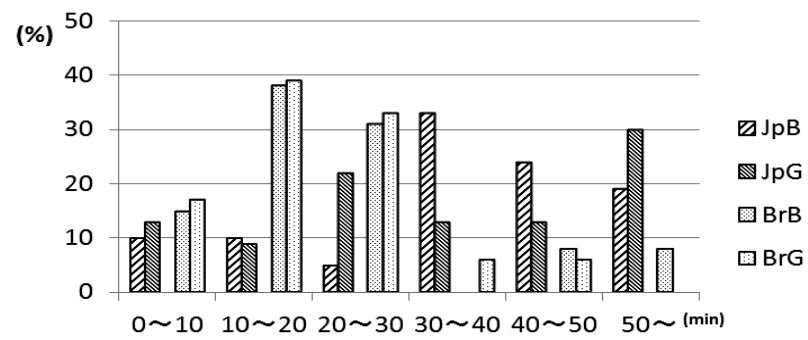

Fig.9 Execution Time 制作時間 
ジであるならば、日本人幼児ばかりでなく、どこの国の幼児にも現 れるはずである。今回、ブラジル人幼児の箱庭作品においても構造 化は同じ原型的空間イメージとって現れたことから、こうした仮説 は再確認されたと言える。

また日本とブラジルの男女幼児に共通して現れた羅列における同 形式の秩序化の作用も、人間の認識作用における原型的なものと考 えることができるだろう。

箱庭作品における文化的差異と建築的表現 : ブラジルでは攻撃性 を表す表現が日本と比較して高い頻度で現れた。部分的構造化およ び構造化の段階で、ブラジル人男子では男性的一元性の空間が 5 例 中 4 例であるのに対して、日本人男子では 9 例中 8 例が多元性の空 間に分類できた。同段階で女子ではブラジル 6 例中 2 例、日本 4 例 中 0 例が男性的一元性の要素をもっていた。それは特に目立つ違い ではないが注 17)、ブラジルでは日本と比較して男女ともに、Table2、 3 の戦い、へビ、始点、羅列の玩具向き、玩具配置の広がり方の各 項目で攻撃性の高さが認められた。

さて森田慶一は建築における日本的表現の性格に関して、西洋建 築に見られる自己顕示型の記念的表現とは対蹠的な自己抑制的な性 格であると指摘する。また伊勢神宮の諸社殿に見られる晴朗、双快 な気分は、ギリシャ建築に見るような理知的な明晰さとは質を異に し、日本建築の明亮性はむしろ情緒的であるともいう注18)。

森田のこうした見解と対応すると考えられる現象を、すでに幼览 の段階でのブラジルと日本の箱庭作品のなかに認めることができる。 すなわち記念的、自己顕示的表現とは、一つの中心が全体を支配す る、左右対称的、垂直的、攻撃的な男性的一元性のイメージに他な らないが、そうした傾向はブラジルでは幼児段階の特に男子箱庭作 品にはっきりと現れているのである。一方、日本的表現が自己抑制 的であることに対応するのは、まさに本稿で分析した攻撃性の低さ と言える。森田は日本的造形には非対称性が顕著なことを指摘する が、それは多元性の空間イメージの基本的性格に他ならない。

森田が指摘する日本的表現の情緒的性格の起源も幼児の箱庭作品 に読みとることができる。それは日本人幼児の男女とも大多数が左 から玩具を置き始める点である。左側が内的世界、無意識界を、右 側が外的世界、意識界を示すとされるが、箱庭療法的心理分析を用 いれば、左側から始まるということは、無意識的、情緒的な内界と のつながりが強いことを表していると解釈できる。また日本人幼児 がブラジル人幼児と比べて箱庭制作を楽しみ、平均で 2 倍近い長時 間遊ぶという事実は、遊ぶという行為自体が無意識的力動の発露で あることを考えれば、これもまた無意識的、情緒的な内界とのつな がりの強さを示すと考えられるのである。

むろん日本人にも相応に自己顕示的な個人は存在するが、成人を 含めて多くの箱庭作品から明らかなように、日本人の一般的傾向と して情緒的な晴朗・明亮さ、穏やかで、非自己顕示的な表現に対す る好みが存在すると考えてもよいであろう。

文化的差異の要因 : 筆者らはこれまでの研究考察により、ブラジ ルと日本の文化的差異は大きく捉えれば欧米と日本の違いと考えて いる。箱庭制作に関してブラジルと日本では幼児段階ですでに顕著 な差が現れていたが、この差は子供に対する大人の姿勢の差、特に 育児法、乳幼児と母親の関係の差などに関連している可能性がある。 日系アメリカ人の人類学者ハルミ・ベフは、日本とアメリカの母親
と乳児の関係、寸なわち日本の育児法とアメリカの育児法の間には 大きな違いがあることを指摘する注 19$)$ 。一例をあげると、アメリカ では多くの場合、生後数週間で乳児を一人寝させ、また授乳は乳児 が空腹で泣こうとも時間に従っておこなわれる。一方日本では子供 が眠ってしまうまで母親が添い寝し、授乳に関しては、ほしがると きに授乳するのが日本の伝統的な方法である。ベフはアメリカ的育 児による情緒的独立は、個人主義イデオロギーに象徵される社会で の独立の心理的な支えとして働いているとする。

子供と彼をとり巻く世界との関係に関して、フランス人地理学者 オギュスタン・ベルクは類似の内容を次のようにまとめている。フ ランスと日本の大人の子供に対する姿勢の違いとして、「フランス の子どもは、大人の世界に慣れなくてはならない。自分たちも参加 できるまで、押しつけられるものを甘受しなくてはならない。逆に 日本では、まさに子どもがまだ社会での役割をしらないが故に、大人

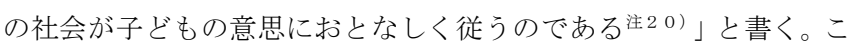
のような欧米で共通する大人の子供に対する姿勢と、外界から受け る圧力を表していると解釈した、玩具が作者に向かって押し寄せて くるN15-BrG5(5)などの作品は関連していると推測できる注21)。

それぞれの文化における育坚法や子供に対する姿勢などは歴史の なかに培われたものである。ブラジルひいては欧米における子供に 対する一般的姿勢は、社会的な攻撃的緊張の高さと対応するかたち で、歴史のなかで習慣として成立してきたものであろう。そしてそ れらは今回のブラジルと日本の箱庭制作実験において顕著に現れた 差異の一つの要因といえるだろう。

欧米および日本の母親と乳児の関係や、広く大人の子供に対する 関係は、ブラジル幼児の自律性に対する日本人幼児の外界との一体 感として分析したことがらの由来を示すものであろう。同時に、ブ ラジルと比較することで日本人幼児の箱庭作品に見てとれた空間的 形式、玩具の向き、広がり方の方向などの具体的な現れ方は、幼児 期以降、個人の外部世界に対する基本的在り方、日本人の世界観、 社会関係に見られる特徴を再考するための新たな視点を与えるもの となると考える。

\section{参考文献}

1) Sakato, S., Kawauchi, A. and Higashino, A.: Research on Human Inventiveness Origins through Kindergarten Children's Sandplay Works, Journal of Architecture and Planning (Transactions of AIJ), Vol. 81, No. 723, pp. 1227-1237, 2016. 5 (in Japanese)

坂戸省三，河内あゆ，東野アドリアナ：保育園児の箱庭制作に見る人間の 創作行為の起源, 日本建築学会計画系論文集, 第 81 巻, 第 723 号, pp. 1227-1237, 2016. 5

2) Sakato, S.: Development of Spatial Representations by Male and Female, Study on the Organizations of Images of Space in the Life Cycle Part 2, Journal of Architecture, Planning and Environmental Engineering (Transactions of AIJ), No. 377, pp. 97-105, 1987. 7 (in Japanese)

坂戸省三：男女それぞれにおける空間性の発達過程, 一ライフ・サイクルと 空間のイメージ構成に関する研究 第 2 報一, 日本建築学会計画系論文報 告集, 第 377 号, pp. 97-105, 1987. 7

3) Sakato, S.: Biological Basis of the Spatialities in Human, Study on the Organizations of Images of Space in the Life Cycle Part 5, Journal of Architecture, Planning and Environmental Engineering (Transactions of AIJ), No. 435, pp. 127-136, 1992.5 (in Japanese) 坂戸省三: 人間における諸空間性の生物学的基盤について,ーライフ・サイ クルと空間のイメージ構成に関する研究 第 5 報一, 日本建築学会計画系 論文報告集，第 435 号, pp. 127-136, 1992.5 
4) Sakato, S.: A Study on the Species-specific Patterns of Spatial Images in the Sand-play-constructions by Female, Journal of Architecture, Planning and Environmental Engineering (Transactions of AIJ), No. 560, pp. 297-304, 2002. 10 (in Japanese)

坂戸省三：女性の箱庭作品において人類共通に見られる空間イメージ とその特徴について, 日本建築学会計画系論文集, 第 560 号, pp. 297-304, 2002. 10

5) Sakato, S.: A Study on the Common Spatial Characteristics in the Sandplay -constructions by Male of the Countries under the Influence of Continental Cultures and their IMAGO MUNDI, Psycho-social analysis on the cultural difference of spatial images Part4, Journal of Architecture and Planning (Transactions of AIJ), No. 572, pp. 185-192, 2003. 10 (in Japanese)

坂戸省三：大陸文化圈男子被験者の箱庭作品に共通して現れる空間的特徴 と彼らの世界像について - 空間イメージの文化的差異に関する心理・社 会的分析 その 4 -, 日本建築学会計画系論文集, 第 572 号, pp. 185-192, 2003. 10

6) Kawai, Hayao: Hakoniwa-ryouhou Nyuumon, Seishinshobou, 1969 (in Japanese)

河合隼雄編: 箱庭療法入門, 誠信書房, 1969

7) Morita, Keiichi: Kenchikuron, Tokai University Press, 1978 (in Japanese)

森田慶一: 建築論: 東海大学出版会, 1978

8) Befu, Harumi: Japan; An Anthropological Introduction, San Francisco, Chandler Publishing Co., 1971

ハルミ・ベフ, 栗田泰之訳：日本 一文化人類学的入門－, 社会思想社, 1977

9) Berque, Augustin: Vivre l'espace au Japon, Presses Universitaires de France, 1982 オギュスタン・ベルク，宮原信訳：空間の日本文化, 筑摩書房, 1985

注

注1）Table3の分類および事例の順（事例番号）は前稿の表 1 と同じである。 なお日本人幼児は 4 歳児組（4歳から 5 歳）、5歳児組（5歳から 6 歳） というように分けて年齢は記録していない。一方ブラジルでは被験者の 年齢のみの記録となった。

注 2) 左下から右上に広がっていくといってもいくつもの仕方がある。例えば、 左下から右に向かって列状に置いてゆき、右端まで達すると2列目が左 端から始まるという具合に、おおよそ列状に進んでいくもの、また同様 に列状に広がるが、左下から左上にゆき、2 列目がまた左下から始まる もの、あるいは列状ではなく、空間的に徐々に左下から右上に広がって いくものなどである。

注 3) 玩具の意味のあるまとまりのうち、狭いものを「場」、比較的広いもの を「領域」と名づけた。

注 4) 場とまで言えないものの、動物や兵隊などの同種の玩具がまとめておい てあったり、隙間的空間で小さな広場のような観を呈したところ。

注 5) 原型的空間イメージは、参考文献 3 で示したように、生物学的な基盤に 由来するものである。前報で見たように構造化された作品は最初からい きなりそのような完成された形式をとって現れてくるということから、 人間の世界認識において、そこにしかるべき様々な内容が盛り込まれる ひな型であると結論づけた。

注 6) その他、20 代前半を中心とした若い女性に世界共通に頻出する「二つの 世界」と呼び慣わされる、川などで全体が二つの領域に分かれたイメー
ジも原型的空間イメージの一つである（参考文献 4）。

注 7) 時間的都合でブラジル側担当者が制作を急がせた例が男子 4 例、女子 3 例あるが、それらは考察から除外した。その他にも幼児年齢以外に 7 歳 から 10 歳までの女子 6 名、男子 2 名に実験をおこなった。

注 8) 例えば項 1、2 に関して、作らずに帰った者はーとなるが、棚前や砂箱 で玩具遊びをした者はそこに記入するか空欄となる。このように事例 により記入箇所が異なる。

注 9) N35-BrB644は上下の」 2 軍団の対決場面であることが注目に值す る。日本では参考文献 2 で小学 3 年生男子では戦いの場面が多数を占 めることを述べたが、それらは左右の軍団の衝突場面で、上下のもの はなかったのである。

注 10) 参考文献 6、pp. 94-103

注 11) 前掲書。p. 35

注 12) 上から下への傾向は女性的一元性の空間イメージとしてはっきりと構 造化された 7 歳から歳 10 の女子の作品にも引き続いて見られた。

注 13) 例えば写真 42 $\rightarrow 43 \rightarrow 44-B r B 611$ は空間的広がり方としては、項 10 中央 $\rightarrow$ 周辺と分類した通りであるが、始点は中中ではなく右中である。つま り項 3 と項 10 必ずしも一致しない。

注 14) 7 歳以上の男子 2 名は右上のみ、7 歳以上の女子でも右上が現れ、6 名 のうち 2 名が右上、3名が左上、1名が左下であった。

注 15）前稿で日本では、砂をかき混ぜる、玩具を砂にめり込ます、上から砂を かけるなどの単純な砂遊びが 4 割ほどの園児に現れ、その感触を通して リラックスし、遊びが誘発されることを示したが、ブラジルではそうし た単純な砂遊びは全く現れていない。

注 16) 参考文献 3 では男性的一元性のイメージについて言及しなかったが、 それは「多元的」なものを「一つの中心」が力でまとめ上げるイメージ である。そして一頭のオスが複数のメスを力でもって支配するゴリラな どの「単雄群」のイメージと重なる。男性的一元性のイメージと単雄群 とは、生物学的に見て、雄の競争的、攻撃的性質が強化されたものとし ての共通性をもつ。

注 17) ブラジル人女子の 7 歳から 10 歳までの年長者の 6 作品はすべて構造 化されたものであったが、5 作品は明確な女性的一元性の空間であっ た。そしてそのうちの 3 作品には強い攻撃性をもつ求心的男性的一元 性のイメージがはめ込まれていた。参考文献 2 で検討した日本人女子 の小学 3 年生の作品にも 6 年生の作品にもそうしたものはない。 成人女子の作品は日本も諸外国もともに女性的一元性の空間イメージ が多く、一見同じように見えるが、ブラジル人女子幼児における攻撃 性の高さ、年長者作品における男性的一元性のイメージを内蔵させた 女性的一元性の空間イメージの多さを見ると、成人女性の作品にも攻 撃性の高さが潜在している可能性が考えられる。

注 18) 参考文献 7、pp. 147-157

注 19) ハルミ・ベフによる記述は参考文献 8 の pp. 227-238による。

注 20) 参考文献 9、p. 52

注 21）欧米人は子供に対して毅然とした態度をとる一方で、それを補償す るかのように、日本人と比較して、強く、はっきりと言語的、身体 的に肯定的感情、愛情を表現しているといえる。 


\title{
SANDPLAY EXPERIMENT STUDY WITH BRAZILIAN AND JAPANESE CHILDREN
}

\author{
Shozo SAKATO ${ }^{* 1}$, Adriana HIGASHINO ${ }^{* 2}$ and Ayu KAWAUCHI*3 \\ ${ }^{* 1}$ Emeritus Prof., National Institute of Technology, Akashi College, Japan, Dr.Eng. \\ ${ }^{* 2}$ Assoc. Prof., Dept. of Architecture, National Institute of Technology, Akashi College, Japan, Dr.Eng. \\ ${ }^{* 3}$ Pacific Consultants Co., Ltd., M.Sc.
}

In this study, through sandplay experiments realized with Japanese and Brazilian children, we will discuss when, from the developmental point of view, the cultural difference appears and their significance.

In previous researches, sandplay works showed several archetypical spatial images. The image named as male spatial singularity has a center axis that integrates all the elements in the sandplay box. It has a vertical axis passing through the center and is usually symmetrical. This type of image often occurred in the works of male subjects with a continental origin, with Western or Eastern cultural background. The image named as spatial plurality shows an asymmetric and a horizontal spread of the toys in the box, and appeared in the works of Japanese male subjects. The image named female spatial singularity has the whole spatial organization centered around a determined space. Inclusion, enclosure, and intimacy are the main characteristic of this type of spatial structure, which appeared in the works of female subjects in general, independent of their nationality or cultural background.

In this experiment, we compared the sandplay works of Japanese and Brazilian kindergarten children. We analyzed the works according to the direction, the position, and the order the children placed the toys in the box, and how long the children played. Japanese children took longer (average play time 36min) and eagerly enjoyed playing with the sandbox and toys than the Brazilian children (average play time 20min). All children's works showed a scale from chaotic, enumeration, partially structured arrangement, to a structured arrangement in the way the children placed the toys in the box. The structured works had archetypical spatial images: male spatial singularity and spatial plurality in boys’ works and female spatial singularity in girls’ works.

Most Japanese children started placing the toys from the left side (inner world) and spread the toys gradually to the right side (outer world). In contrast, Brazilian children from the early age of 5 years placed the toys from the center of the box to the outside (boys) and from top to bottom (girls). Brazilian children showed domination of the space in the box in whole, proactively, aggressively expressed their ego, and showed a strong force pushing to the outer world. Brazilian children's works presented a higher level of aggressivity in the placement of the toys. Also, compared with Japanese children a more significant number of Brazilian boys’ sandplay works showed the typical characteristics of male spatial singularity, which express male aggressiveness. Japanese children sandplay works revealed a sense of unity with the surrounding world in contrast to Brazilian children that from an early age separate themselves from the world and had an autonomous tendency.

In resume, Brazilian boys from an early age showed in their sandplay works the male spatial singularity, archetypical spatial image of male adults with a continental cultural background. Brazilian girls also showed the archetypical female spatial singularity, but there were aggressiveness traits on the way of placing the toys. Japanese children sandplay works indicate a sense of unity with the outside world in contrast to the autonomy of Brazilian children, which were raised in a more hostile environment. The appearance of archetypical spatial images at an earlier age in Brazilian children's sandplay works confirms that the relationship with the outside world has an impact on individuals from the early childhood. 